XLI Reunião Anual da Sociedade Brasileira de Bioquímica e Biologia Molecular - SBBq Foz do lguaçu, PR, Brasil - 19 a 22 de maio de 2012

\title{
Creation Group of Educational Objects in Biochemistry (GCOEB)
}

Vera Maria Treis Trindade, Geancarlo Zanatta, Pablo Ricardo Arantes, luri dos Santos Blanco e Christianne Gazzana Salbego

Dep. de Bioquímica, ICBS, UFRGS, RS, Brazil

The Creation Group of Educational Objects in Biochemistry started in 2009 in order to virtually organize practical-laboratory activities in Biochemistry I, of Pharmacy Course, UFRGS, through presentation type files (power point) with detailed photos of technical procedures, reagents, equipment and possible results, all associated with challenging questions. Gradually these activities are being transformed into virtual versions of the Flash program, mixing photos, cartoons and proposed interactivities. These simulations aim to help the students in the consolidation of the theoretical and practical biochemical knowledge. We believe that these pedagogic tools support the learning of Biochemistry, increase the scientific curiosity, stimulate the presence in the laboratory and never replace it. (www6.ufrgs.br/gcoeb/)

Word Keys: Educational Objects, software

Supported by: SEAD-UFRGS, CNPq 
This document was created with Win2PDF available at http://www.win2pdf.com. The unregistered version of Win2PDF is for evaluation or non-commercial use only. This page will not be added after purchasing Win2PDF. 